\title{
Sex and pleasure in western culture
}

Gail Hawkes; Polity Press, Cambridge, 2004, 224p, ISBN 0-7456-1670-4£50 (Hbk);

ISBN 0-7456-1671-2£15.99 (Pbk)

In Sex and Pleasure in Western Culture, Gail Hawkes gives a useful 'broad sweep' (p. 2) overview of ideas about sex and pleasure through Western culture - a task that has hitherto been attempted surprisingly rarely. This is the book's primary strength.

Hawkes' sociological background is clear throughout the text. Hawkes demonstrates the socially constructed nature of ideas about sexuality: how sexual beliefs both vary over time and endure in varied and remoulded forms. One of her core aims is to point out, in a broadly Foucauldian vein, that social order is connected to sexual order: the sexual body is brought into line through discourses about sexuality that arise from the priorities and beliefs of different historical periods. A history of sexuality is a brave topic for a sociologist to attempt, and Hawkes is alert to the potential danger of taking historical evidence and interpreting it out of its context. She appears to write for social scientists more than for historians, hoping to convince the former that 'the past can contribute much to an understanding of the present' (p. 2).

She begins with what she calls 'the sexual landscape of the new millennium'. Because this section draws so specifically from the late 1990s up to 2002 this risks dating the book and might be better left to the end. The text then turns to classical antiquity and progresses through early Christianity, the Middle Ages and the Renaissance before moving to modernity and the 20th 'sexual century'. Her periodization might be judged overly simplistic, but it is a likely consequence - some might argue necessity - of attempting such an ambitious project.

Achieving a fruitful balance between specific detail and general observation is a priority for an author of such a text. For the most part, Hawkes does this well. For example, in the chapter 'Guilty Sex, Courtly Love and the Unruly Body: Medieval Themes and Practices' she identifies both a general tension 'between irrational pleasure and rational control' (pp. 82-83) and provides interesting detail on how medieval medical tracts and theologians sought to approve sexual pleasure but regulate it in highly specific ways. And while she details early Christianity's condemnations of 'sinful sex' she is sufficiently attuned to the complexity of Christianity's presentation of sexuality to identify these prohibitions as not so much theological as historically contextual.

Understandably, given the priority given to heterosexuality in Western culture, the book concentrates more on heterosexuality than on other sexualities. Yet Hawkes does not ignore sexual diversity. She covers, for example, the way the classical 
era's ideas about how the exercise of 'self-mastery' in relations between men and boys contributed to the production of appropriate masculinity. And, as would be expected, she recognizes that the modern construction of the figure of the homosexual is linked to what Laqueur (1990) has identified as the creation of two separate sexual spheres.

Less positively, although the subject matter is interesting, contrary to the publisher's blurb, I did not find the book 'a compelling read'. Partly this is a problem related to the publisher's style and layout but Hawkes' writing style also at times feels laboured rather than engaging.

Feminist insights are included but are not central, and where power is discussed it is not as often as might be expected identified as gendered or racialized. Issues of ethnic diversity are absent, and while this is of course a text on a predominantly Caucasian culture, one would expect some mention of how the ideas she invokes are connected to an imperialist project involving distorted ideas about the sexuality of non-white people.

But these criticisms apart, Sex and Pleasure in Western Culture will provide a useful introduction to ideas about sexuality for students, academics and general readers.

\section{reference}

Kristin Aune

Laqueur, T. (1990) Making Sex: Body and Gender from the Greeks to Freud, Cambridge, MA: Harvard University Press.

doi: $10.1057 /$ palgrave.fr. 9400369

\section{Violence and the body: race, gender, and the state}

Arturo J. Aldama (editor); Indiana University Press, Bloomington, Indiana, 2003, 400p, ISBN 0-253-21559-5, £21.50 (Pbk); ISBN 0-253-34171-X, £57.00 (Hbk)

In 'On The Subject of Violence', Roland Barthes (1985) asserts that 'one must choose one's key to discuss violence'. In editor Arturo J. Aldama's collection of 23 essays, Violence and the Body: Race, Gender and the State, 'the body' is offered as such a key. In his introduction, Aldama states his intention to 'create a dialogic space to explore the relationships between discursive violence' and the 'materiality of violence'. The book provides 'an alternative political and theoretical space where feminist work on the social construction of the body' can intersect with 'women of color theories of the multiplicity of oppression and 